\title{
Analisis Densitas Larutan Berbasis Citra Phantom Agar dalam Kendali Mutu USG
}

Carolina Febe Ronicha Putria, Giner Maslebu ${ }^{a^{*},}$ Andreas Setiawan ${ }^{\mathrm{a}}$

aProgram Studi Fisika, Fakultas Sains dan Matematika, Universitas Kristen Satya Wacana, Jl. Diponegoro 52-60, Salatiga, Jawa Tengah, Indonesia, 50711.

*Email : giner.maslebu@uksw.edu

(Diterima 18 Januari 2021; Disetujui 18 Juli 2021; Dipublikasikan 15 Oktober 2021)

\begin{abstract}
Abstrak
Salah satu peralatan yang digunakan untuk uji kontrol atau diagnosa pada pasien adalah Ultrasonografi (USG). Kualitas citra dari hasil pesawat USG sangat penting karena mempengaruhi hasil scan pada pasien sehingga perlu dilakukan uji kontrol kualitas pada USG. Salah satu alat yang dapat digunakan untuk uji kontrol kualitas pada USG adalah Phantom Ultrasound. Phantom dibuat berbahan dasar agar dengan komposisi $750 \mathrm{ml}$ air dan $7 \mathrm{~g}$ bubuk agar. Keunggulan phantom model ini adalah mudah dibuat dan mirip jaringan lunak karena komposisi utamanya adalah $\mathrm{H}_{2} \mathrm{O}$, namun kelemahan utamanya adalah tidak dapat digunakan dalam jangka waktu yang lama karena mudah berjamur. Penelitian ini dilakukan untuk mengetahui uji kualitas USG dengan melakukan analisis densitas larutan gula dengan berbagai macam konsentrasi dan penentuan jarak obyek berbasis citra phantom hasil pemindaian USG. Aplikasi perangkat lunak Image-J digunakan dalam pengolahan data pada menu Histogram untuk melihat nilai aras keabuan dan straight-line plot untuk mengukur kedalaman obyek pada phantom. Hasil analisa data menunjukkan bahwa semakin tinggi konsentrasi gula dalam suatu larutan maka nilai densitas larutan dan aras keabuan citra larutan semakin tinggi yang dibuktikan dengan pola grafik linier hubungan parameter-parameter tersebut dan kedalaman obyek yang berbeda-beda dari permukaan phantom dapat dihitung berdasarkan jarak piksel pada citra.
\end{abstract}

Kata kunci: Aras keabuan, Densitas, USG

\section{Latar Belakang}

Aplikasi dan pemanfaatan gelombang ultrasound telah berkembang, salah satunya pada diagnosa pasien. Salah satu peralatan yang digunakan untuk uji kontrol pada pasien adalah Ultrasonografi (USG). Dalam penggunaannya, tentu yang menjadi faktor penting adalah kualitas citra dari hasil pesawat USG karena mempengaruhi hasil scan pada pasien sehingga perlu dilakukan kontrol kualitas USG. Alat untuk uji kontrol kualitas yang digunakan saat ini adalah kadaver dan phantom ultrasound $[1,2]$

Pada tahun 2008, A. J. D. Frederick Ayers meneliti tentang fabrikasi dan karakterisasi jaringan phantom berbasis silikon dengan sifat optik dalam domain inframerah tampak dan dekat. Jaringan simulasi phantom optik memainkan peran sentral dalam pengembangan, validasi, dan penerapan teknologi biomedis berbasis optik [1]

Penggunaan jaringan simulasi phantom optik merupakan bagian penting dari pengembangan lanjutan dan adopsi dari teknik-teknik klinis berbasis optik. Phantom cair paling mudah diproduksi dan dikarakterisasi, meskipun ada sejumlah aplikasi phantom padat sebagai opsi model permanen yang lebih cocok. Beberapa penelitian sebelumnya telah membuat phantom ultrasound dengan berbahan dasar gelatin, agar, gel parafin dan sillicon rubber [3-5]. Phantom dengan berbahan dasar gel parafin memiliki kekurangan yaitu kesulitan dalam mengubah kecepatan suara dari material yang digunakan[6].

Phantom berbahan dasar agar cukup menjanjikan untuk pembuatan phantom ultrasound, selain memiliki harga yang tidak terlalu mahal, agar juga mudah dalam perawatannya karena tidak membutuhkan pendingin, phantom berbahan dasar agar juga memiliki kemiripan struktur dengan jaringan yang ada pada manusia terutama jaringan lunak, tidak mudah mencair dan dapat digunakan berkali-kali[7].

Untuk mengetahui mutu dan kelayakan uji kualitas USG akan dilakukan analisis densitas larutan dengan berbagai macam konsentrasi larutan. Konsentrasi larutan menunjuk pada kepekatan suatu larutan, berarti dibutuhkan zat terlarut untuk membandingkan antara kepekatan zat satu dengan yang lainnya, untuk itu dibutuhkan 
densitas larutan. Semakin besar konsentrasi larutan maka semakin besar pula densitas larutan secara fisis akan dapat dilihat dengan USG bagaimana citra derajat keabuan yang akan dihasilkan apakah semakin tinggi densitas dan konsentrasi nilai keabuannya semakin meningkat atau semakin menurun. Keterbaruan dari penelitian ini adalah pembuatan phantom berbasis agar dengan penempatan beberapa obyek secara statis pada kedalaman tertentu yang berisi larutan untuk analisis kendali mutu USG berbasis perangkat lunak pengolahan citra.

\section{Metodologi}

Phantom agar dibuat dengan komposisi $750 \mathrm{ml}$ air dan $7 \mathrm{~g}$ bubuk agar dengan obyek yang dipakai adalah sedotan yang memiliki diameter dengan ukuran yang sama. Sedotan tersebut diisi dengan air gula dengan konsentrasi yang berbeda, dalam hal ini digunakan air sebanyak $50 \mathrm{ml}$ kemudian diberi gula dengan masing-masing takaran $5 \mathrm{~g}, 10 \mathrm{~g}$, 15 g, 18 g, 20 g, 25 g, dan 30 g. Kemudian dilakukan pemindaian obyek menggunakan modalitas USG 3D Mindray DP-10. Hasilnya berupa citra yang selanjutnya diolah menggunakan aplikasi Image-J [8]. Analisis dilakukan dengan pemilihan menu histogram untuk mempelajari nilai aras keabuan (gray value) pada mean obyek dan plot data untuk mengukur kedalaman obyek yang berbeda-beda, yaitu $1 \mathrm{~cm}, 3 \mathrm{~cm}$, dan $4 \mathrm{~cm}$.

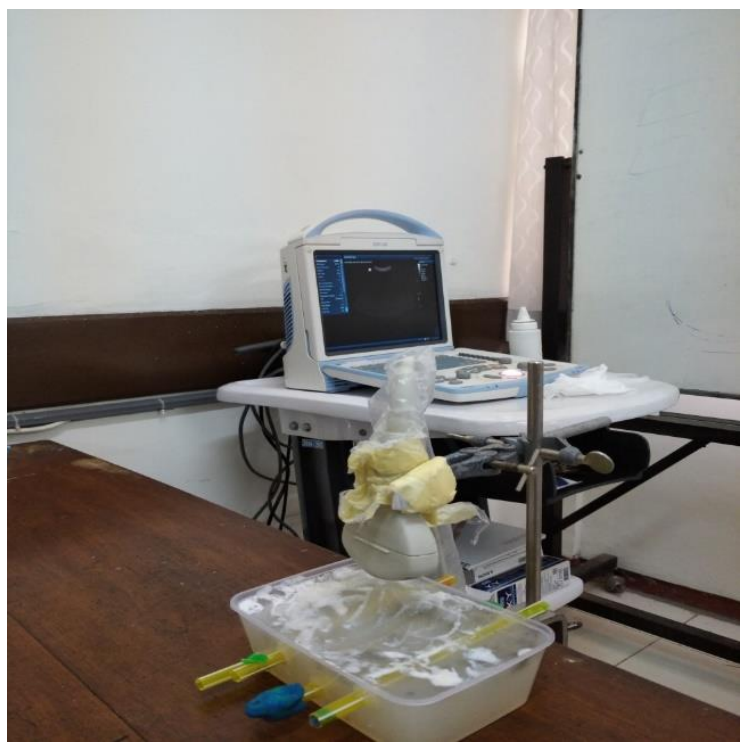

Gambar 1. Proses scanning data menggunakan USG

\section{Hasil dan Pembahasan}

Phantom yang digunakan sebagai instrumen pengambilan data adalah phantom berbahan dasar agar dengan komposisi $750 \mathrm{ml}$ air dan $7 \mathrm{~g}$ bubuk agar. Tahapan dalam analisis dimulai dengan scanning data pada phantom kemudian melakukan processing image menggunakan aplikasi Image-J [8] dengan memilih tools Histogram dan Plot. Tools Histogram digunakan untuk melihat aras keabuan untuk melihat nilai derajat keabuan masing-masing cairan, kemudian plot digunakan untuk melihat jarak obyek dari permukaan phantom.

Penelitian ini menggunakan $50 \mathrm{ml}$ air dengan masing-masing takaran gula 5 g, 10 g,15 g, 18 g,20 g,25 g, dan $30 \mathrm{~g}$, dan scanning data dilakukan sebanyak 10 kali tiap larutan gula. Kemudian untuk mengetahui nilai densitas masing-masing larutan maka digunakan rumus[9]:

$$
\rho=\frac{m}{V}
$$

$\rho=$ Massa Jenis $\left(\mathrm{kg} / \mathrm{cm}^{3}\right)$

$\mathrm{m}=$ Massa $(\mathrm{kg})$

$\mathrm{V}=$ Volume larutan $\left(\mathrm{cm}^{3}\right)$

Untuk mencari nilai konsentrasi pada larutan gula maka menggunakan rumus konsentrasi larutan:

$$
C=\frac{m}{V}
$$

$\mathrm{C}=$ Konsentrasi Larutan gula $(\mathrm{g} / \mathrm{ml})$

$\mathrm{m}=$ Massa gula $(\mathrm{g})$

$\mathrm{V}=$ Volume air $(\mathrm{ml})$

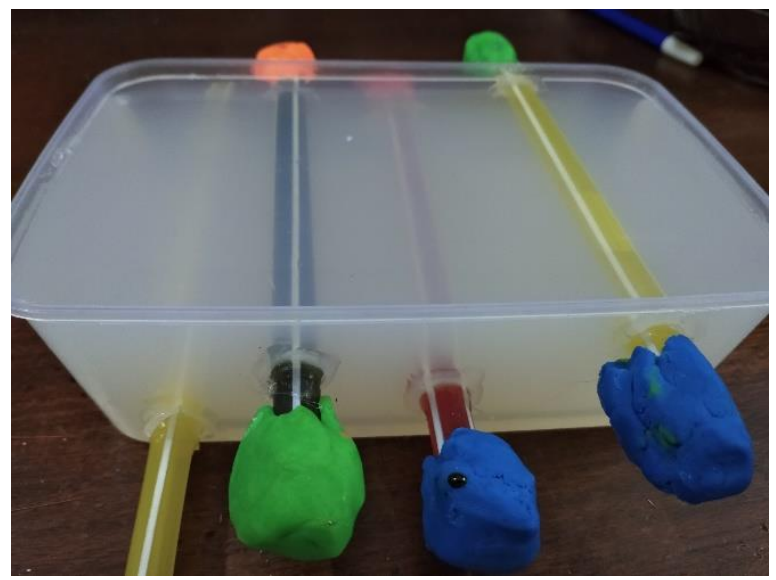

Gambar 2. Phantom agar 
Tabel 1. Densitas Larutan dan Konsentrasi Gula

\begin{tabular}{|c|c|}
\hline Densitas $\left.\mathbf{( k g} / \mathbf{c m}^{3}\right)$ & Konsentrasi $\mathbf{( g / m l )}$ \\
\hline 972 & 0 \\
\hline 987 & 0,1 \\
\hline 1.027 & 0,2 \\
\hline 1.045 & 0,3 \\
\hline 1.056 & 0,36 \\
\hline 1.076 & 0,4 \\
\hline 1.098 & 0,5 \\
\hline 1.114 & 0,6 \\
\hline
\end{tabular}

Grafik densitas terhadap konsentrasi larutan gula diberikan pada Gambar 3.

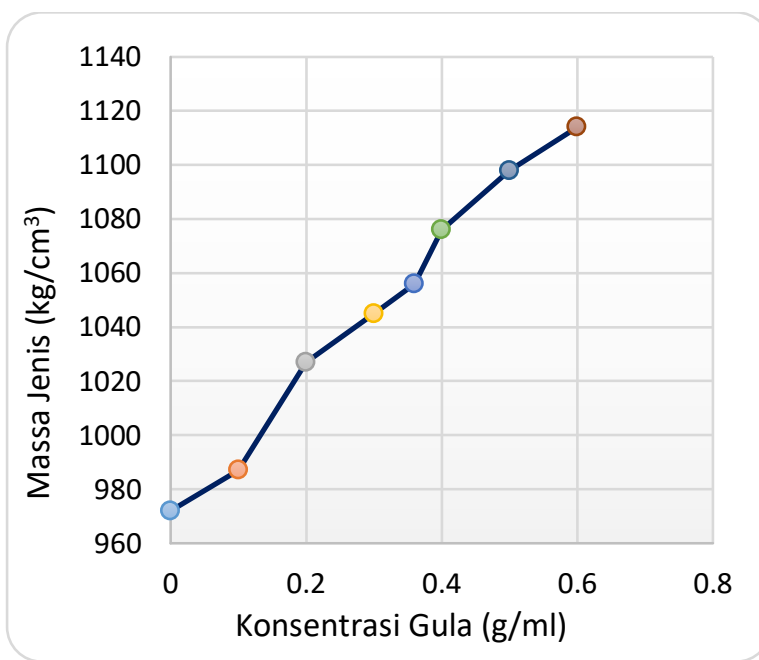

Gambar 3. Grafik densitas terhadap konsentrasi

Gambar 3 menunjukkan bahwa semakin tinggi konsentrasi larutan maka nilai densitasnya juga akan semakin besar.

Untuk mencari nilai aras keabuan pada larutan, maka digunakan cara memotong gambar hasil scanning phantom kemudian memotong daerah yang dianalisis sebagai Region of Interest (ROI) berbentuk lingkaran dengan ukuran yang sama tiap pengambilan datanya seperti pada Gambar 4 . Setelah itu pada ROI dihitung nilai rerata keabuannya melalui fitur histogram yang ada pada ImageJ. Grafik histogram dan bacaan nilai keabuan dapat dilihat pada Gambar 5.

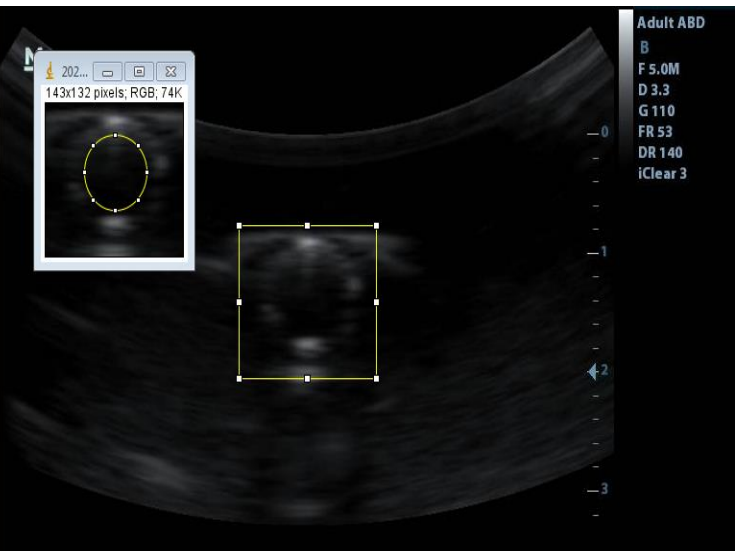

Gambar 4. Pemotongan ROI

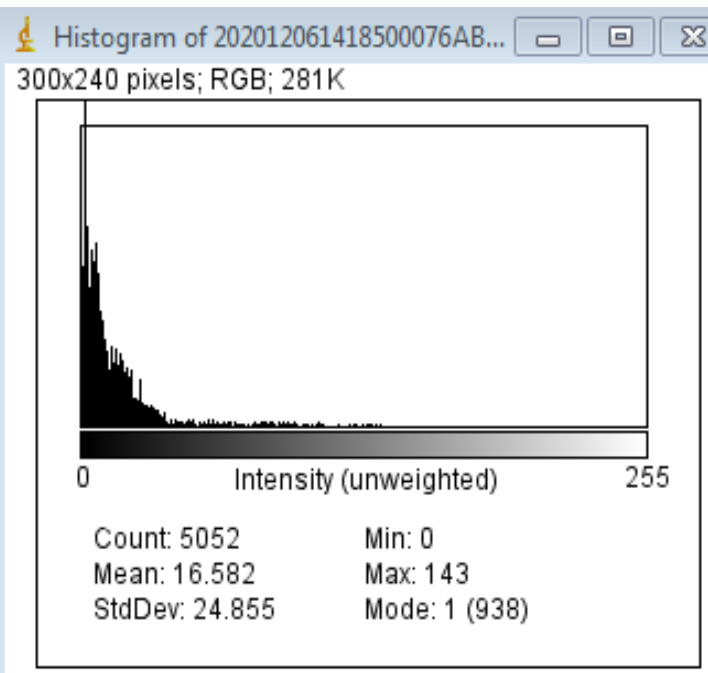

$$
\begin{array}{l|l|l|l|l|}
\text { List } & \text { Copy } & \text { Log } & \text { Live } & \text { RGB } \\
\hline
\end{array}
$$

Gambar 5. Histogram berdasarkan ROI yang dipilih

Pada saat pemindaian obyek, dilakukan $10 \mathrm{kali}$ pengulangan pada masing-masing larutan gula kemudian dicari nilai rata-ratanya berbasis pengolahan citra. Hasil perhitungan nilai mean gray value yang didapat dari 7 larutan ditunjukkan pada Tabel 2.

Tabel 2. Tabel nilai rerata (mean) gray value

\begin{tabular}{|c|c|c|c|}
\hline $\begin{array}{c}\text { Air } \\
(\mathbf{m l})\end{array}$ & $\begin{array}{c}\text { Gula } \\
\text { (g) }\end{array}$ & $\begin{array}{c}\text { Konsentrasi } \\
(\mathbf{g} / \mathbf{m l})\end{array}$ & $\begin{array}{c}\text { Mean (Gray } \\
\text { Value })\end{array}$ \\
\hline 50 & 0 & 0 & 4,727 \\
\hline 50 & 5 & 0,1 & 9,45 \\
\hline 50 & 10 & 0,2 & 10,942 \\
\hline 50 & 15 & 0,3 & 13,279 \\
\hline 50 & 18 & 0,36 & 13,4 \\
\hline 50 & 20 & 0,4 & 15,363 \\
\hline 50 & 25 & 0,5 & 16,188 \\
\hline 50 & 30 & 0,6 & 17,275 \\
\hline
\end{tabular}




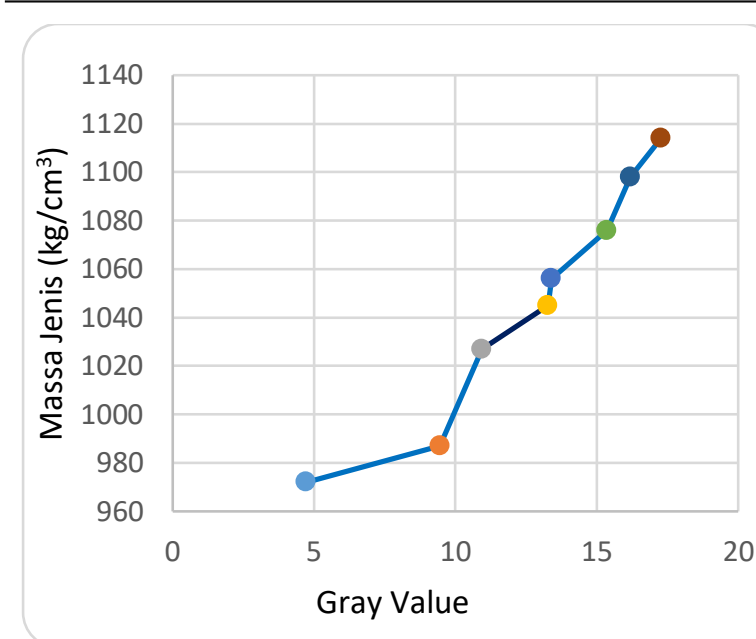

Gambar 6. Grafik Korelasi Densitas dengan Aras keabuan (Gray Value)

Nilai mean obyek yang telah diketahui merupakan nilai aras keabuan dari tiap larutan gula secara spesifik. Grafik korelasi antara nilai densitas larutan dengan gray value diberikan pada Gambar 6.

Dari Gambar 6 dapat dilihat bahwa semakin besar nilai densitas larutan di dalam phantom maka nilai dari aras keabuan citranya juga akan semakin besar yang menunjukkan bahwa kedua parameter fisis dan imaging ini memiliki hubungan yang sebanding. Hasil pemindaian phantom berupa obyek-obyek pada kedalaman berbeda dari permukaan ditunjukkan pada Gambar 7 .

Jarak permukaan phantom ke obyek diukur menggunakan Image-J dengan pemilihan tools straight line (garis warna lurus kuning) seperti pada Gambar 8. Selanjutnya dilakukan plot histogram dengan sumbu-x menunjukkan jarak (distance) dalam piksel seperti pada Gambar 9.

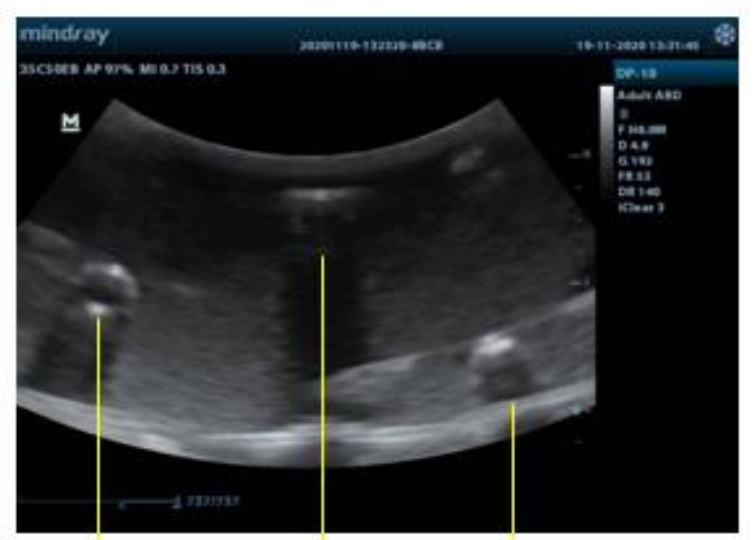

\section{Objek 1 Objek 2 Objek 3}

Gambar 7. Posisi obyek hasil pencitraan

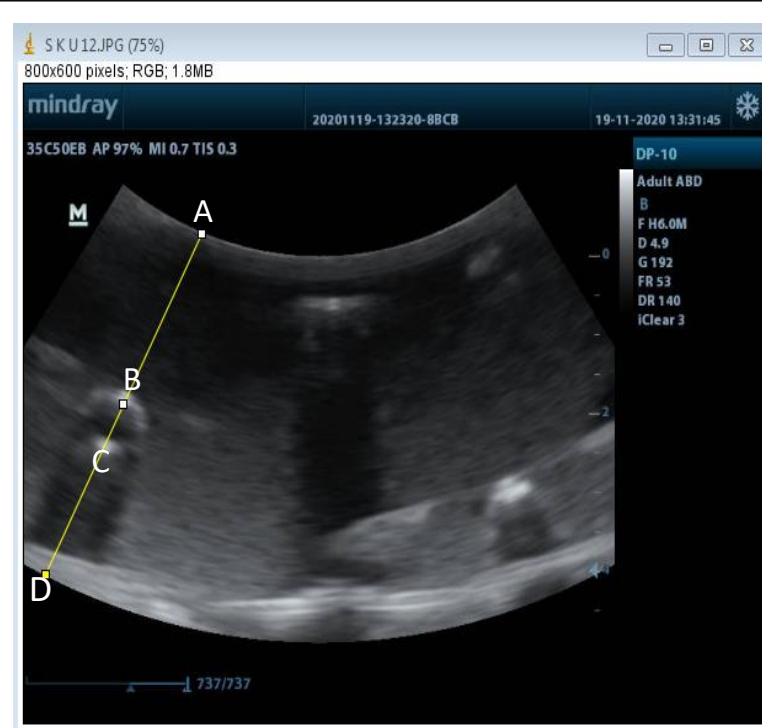

Gambar 8. Penggambaran garis lurus (ditandai dengan garis kuning) pada citra USG untuk menentukan kedalaman obyek dari permukaan phantom mulai dari titik A, B, C sampai D.

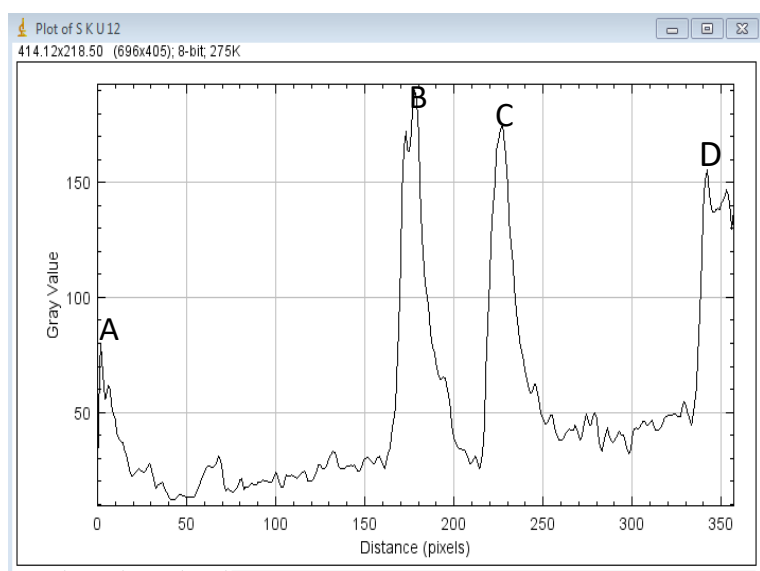

List Data : More : Live

Gambar 9. Plot aras keabuan yang dibaca oleh Image-J sepanjang garis yang digambar pada Gambar 8.

Pada Gambar 9, A adalah posisi permukaan obyek (puncak nilai aras keabuan A), puncak nilai aras keabuan B dan C menunjukkan batas jarak diameter obyek, sedangkan puncak D merupakan batas bawah phantom. Kedalaman atau jarak obyek dari permukaan ditentukan dari nilai distance puncak A (0 piksel) sampai nilai tengah antara distance $\mathrm{B}$ dan $\mathrm{C}$ sebagai indikator centroid (pusat) dari obyek. Dari model analisa tersebut, maka didapatkan data pada obyek 1 nilai jaraknya adalah 209,0431 piksel dengan nilai riil $2 \mathrm{~cm}$, obyek ke 2 diketahui nilainya adalah 98,0051 piksel dengan nilai riil $1 \mathrm{~cm}$, dan obyek 3 diketahui nilainya adalah 360,1389 piksel dengan nilai riil $4 \mathrm{~cm}$. Hasil ini menunjukkan bahwa penggunaan tools line dan plot 
histogram pada aplikasi image-J dapat digunakan untuk menentukan kedalaman yang berbeda dari obyek-obyek di dalam phantom agar.

\section{Kesimpulan}

Penelitian ini bertujuan untuk mengetahui metode untuk menganalisis uji kontrol kualitas USG menggunakan phantom berbahan dasar agar dan teknik komputasi berbasis aplikasi pengolahan citra. Berdasarkan hasil yang didapat, phantom yang terbuat dari agar dengan komposisi $750 \mathrm{ml}$ air dan 7 gram bubuk agar dapat digunakan sebagai phantom sederhana untuk melakukan uji kontrol kualitas USG. Analisis data menunjukkan adanya korelasi antara densitas larutan terhadap konsentrasi gula, yakni semakin besar nilai densitas larutan gula maka konsentrasinya semakin besar juga. Berdasarkan warna aras keabuan, ditemukan bahwa semakin besar nilai densitas larutan maka nilai aras keabuan juga akan semakin besar. Kedalaman obyek bisa ditentukan berdasarkan nilai distance (jarak) piksel dari permukaan phantom ke posisi masing-masing obyek. Beberapa puncak tingkat keabuan yang muncul pada grafik distance vs. gray value dalam analisis jarak menunjukkan batas atas (permukaan) dan batas bawah dari phantom serta ukuran obyek.

\section{Daftar Pustaka}

[1] Frederick Ayers, Alex Grant, Danny Kuo, David J. Cuccia, A. J. D. , Fabrication and characterization of silicone-based tissue phantoms with tunable optical properties in the visible and near infrared domain, SPIE, 6870pp.1-9, 2008.
[2] Yusanti, W. , Setia, W. , and Adi, K. , Penentuan Quality Control (Qc) Resolusi Spasial Pada Citra Ct Scan Dengan Metode Line Spread Function (Lsf) Dan Point Spread Function (Psf) Menggunakan Phantom Aapm Ct Performance, Berkala Fisika, 17(2), pp.39-44, 2014.

[3] Dustin S Morrow, Julia A Cupp, J. S. B. , Versatile, Reusable, and Inexpensive Ultrasound Phantom Procedural Trainers, Ultrasound Med, (831841), 2016.

[4] Ratar, V. I. , Trihandaru, S. S. , and Maslebu, G. , Analisis Resolusi Spasial Citra Ultrasonografi (USG) pada Arah Tangensial Radias Citra menggunakan Phantom Berbasis Silicon Rubber, Jurnal Fisika dan Aplikasinya, 16(1), pp.1, 2020.

[5] Siti Fatimah, Giner Maslebu, S. T. , Analisis Homogenitas Citra Ultrasonografi Berbasis Silicone Rubber Phantom dengan GLCM, Jurnal Fisika, (18-27), pp.1-10, 2018.

[6] Vieira, S. L. , Pavan, T. Z. , Junior, J. E. , and Carneiro, A. A. O. , Paraffin-Gel Tissue-Mimicking Material for Ultrasound-Guided Needle Biopsy Phantom, Ultrasound in Medicine and Biology, 39(12), pp.2477-2484, 2013.

[7] Earle, M. , Portu, G. De , and Devos, E. , Agar ultrasound phantoms for low-cost training without refrigeration, African Journal of Emergency Medicine, 6(1), pp.18-23, 2016.

[8] Ridha, M. and Darminto, D. , Analisis Densitas, Porositas, dan Struktur Mikro Batu Apung Lombok dengan Variasi Lokasi dan Kedalaman, Jurnal Fisika dan Aplikasinya, 12(3), pp.124130, 2016.

[9] Antika, L. , Julianty, E. , Miroah , Nurul, A. , and Hapsari, F. , Pengukuran (Kalibrasi) Volume dan Massa Jenis Alumunium, Jurnal Fisika dan Aplikasinya, 13(1), pp.22-28, 2012. 